\title{
THE ROLE OF JUST-IN-TIME IMPLEMENTATION IN RELATION TO PERFORMANCE: AN EXPLORATORY STUDY
}

\author{
Che Ruhana Isa and Tay Yew Keong
}

\begin{abstract}
This study investigates the relationship between the level of just-in-time (JIT) purchasing and manufacturing implementation and performance. The study employed a self-administered questionnaire survey to collect data from Malaysian manufacturing companies. The statistical tests provide empirical evidence that the level of JIT implementation is related to perceived performance. The findings reveal that the level of JIT adoption is positively related to both financial and non financial performance. In addition, the t-test results indicate that there are significant differences in the level of performance among the JIT firms and the non-JIT firms.
\end{abstract}

Keywords: Just-in-time, manufacturing firms, performance, Malaysia

\section{Introduction}

Over the last two decades, firms globally have faced increasing pressure to attain and sustain a competitive position and performance in the dynamic and competitive markets. To survive in such a competitive environment, firms need to come up with strategies consistent with its environmental demands for efficiency, effectiveness and customer responsiveness. In view of the escalating threats from global players, especially those from China, Malaysian manufacturing firms are compelled to continuously review their strategies and devise plans to improve their operations if they are to survive and prosper. Currently, products from China have flooded the Malaysian market at very competitive prices and for the Malaysian manufacturers to counter the impending threats successfully; they need to be more efficient in their operations so that their manufacturing performance can be improved.

One of the strategies to improve manufacturing performance is the adoption of worldclass, lean and integrated manufacturing strategies such as just-in-time (JIT) system (Fullerton \& McWatters, 2002). Some of the benefits of JIT are that it allows companies to reduce cost, meet customer's demands, stay ahead of competitors and minimise slack resources, which are critical for survival in the increasingly competitive market (Cobb, 1993). The focus of JIT is cost reduction and excellence through continuous improvements in the business process by redefining the structural and procedural activities performed within an organization (Fullerton \& McWatters, 2002). To achieve this, constant evaluation of the changes in quality, setup times, defects, rework, and throughput time is imperative.

The purpose of the research is to examine the level of JIT implementation among Malaysian manufacturing firms and to evaluate empirically the relationship between the JIT implementation and performance. Thus far, the literature review reveals that there is no

Corresnponding author: Dr Che Ruhana Isa, Associate Professor, Faculty of Business and Accountancy, University of Malaya (cruhana@um.edu.my). Co-authoured: Tay Yew Keong, Postgraduate Student, Faculty of Business and Accountancy, University of Malaya. 
published study on JIT in Malaysia. The findings of this study will be able to improve our understanding on the extent of JIT implementation among manufacturing firms in Malaysia. In addition, this study will provide valuable insights into the relationship between JIT implementation and performance, which will assist us in determining whether JIT firms have a competitive edge in today's intense competitive environment.

The following sections of the paper are organised as follows. The next section examines the prior literature related to JIT and organizational performance and outlines the research hypotheses. Section 3 describes the research method. Section 4 presents and discusses the findings. The final section summarizes the study, and identifies limitations and further research directions.

\section{Literature Review}

\subsection{The JIT Philosophy}

JIT philosophy was developed in Japan by Toyota Motor Company with the aim of continuously eliminating waste and improving productivity (Ansari and Modarress, 1990). The essence of JIT is the elimination of waste through elimination of non-value added activities in purchasing, manufacturing, distribution, and manufacturing support activities of the manufacturing process. According to Cobb (1991), there are three main elements of JIT philosophy as identified by Hay (1988): quality, employee involvement and production flow. JIT stresses continuous quality improvement by striving for zero defects through product design, process design and supplier quality, which require employee involvement and commitment. To achieve a steady flow of production, JIT proposes five interrelated elements: uniform factory load, set up time reduction, machine cells, pull system and JIT purchasing.

JIT manufacturing is a demand-pull system where products are produced when orders are received from customers and only in the quantities demanded by the customers. JIT manufacturing is defined as a repetitive production system in which processing and movement of material and goods occurs just as they are needed, usually in small batches (Stevenson, 1996). This manufacturing system includes practices of preventive maintenance, cellular manufacturing, continuous flow, smaller lot sizes and kanban (Foster \& Hongren, 1987; Fullerton \& McWatters, 2002). Thus, manufacturing plants have to be reorganized so that raw materials and purchased parts are delivered to the plant right before they are entered into the production process.

The JIT approach to manufacturing must consist of the following building blocks: company-wide commitment, proper materials at the right time, supplier relationships, long term contract, quality and personnel (Ansari and Modarress, 1990). Top management support and commitment from all levels of staff are among the most important factors that ensure JIT success through adequate financial commitment and proper planning before implementation of a JIT manufacturing system (Shannon, 1993). The JIT purchasing system must be in place to support the JIT manufacturing system. In this system, materials are purchased in small quantities from a few reliable suppliers and delivered frequently, just before they are needed for production. By reducing the number of suppliers and improving relationships with these valued partners, JIT firms will benefit from cost and time saving. By ordering small batches that are consumed, almost as soon as they arrive, an organization can benefit from space saving, which results from holding much less inventory as well a drastic reduction in the costs associated with holding large amounts of inventory. These, in most cases, are higher than the freight costs and smaller discounts associated with the smaller lot size purchases. These cost savings can then be allocated to alternative uses to improve the overall success of the organization (Ptak, 1997). 


\subsection{JIT and Performance}

Successful application of the JIT philosophy of cost reduction is argued to lead to improvements in both financial and non-financial performance such as lower production costs, higher and faster throughput, improved product quality and on-time delivery of products, which should eventually result in improved profitability (Fullerton et al., 2003). It has been argued that JIT adoption might lead to improved operations but does not necessarily always result in higher profitability (Johnson and Kaplan, 1989), particularly in the short term. Cooper (1995) argues that companies should not expect JIT implementation to result in financial benefits in the short term but they could instead learn from their Japanese counterparts who emphasize more on stability, long-term reliability, and growth. Comparing Japanese and U.S. transplant manufacturing firms, Nakamura et al. (1998) show that the Japanese firms' short term profits were consistently lower. Consistent with this view, Johnson and Bröms (2000) reveal that it is Toyota's manufacturing strategies that promote growth and stability over the long run and not the achievement of short-run financial targets that contribute to its stable performance.

Thus, the focus on financial performance alone is not sufficient for firms to survive and excel in today's market. Kaplan (1984) proposes that non-financial measures of manufacturing performance such as quality, inventory, productivity, innovation, and workforce must also be considered. Manufacturing companies must be totally committed to quality; that is, each product must be manufactured strictly according to specification. It has been argued that an exclusive reliance on financial measures in a management system is insufficient and companies should also focus on non-financial performance indicators for long term growth and sustainability (Kaplan and Norton, 1992). A performance measurement system based solely on financial reporting indicators has limitations because it focuses on past performance and takes a short-term view of strategy. Exclusive reliance on these indicators could lead managers to focus on short-term performance at the expense of the opportunity to evaluate and develop strategies for long-term value creation. The Balanced Scorecard approach maintains measures of financial performance, but supplements these with measures of the lead indicators or key success factors of future financial performance.

Previous studies that examined the direct relationship between JIT implementation and financial performance show mixed results (Balakrishnan et al., 1996; Huson and Nanda, 1995; Inman and Mehra, 1993; Kinney and Wempel; 2002). Inman and Mehra (1993) reported a significant correlation between self-reported improvement in performance and the adoption of JIT practices. On the other hand, Balakrishnan et al. (1996) found that there were no differences in return on assets (ROA) among JIT and non-JIT firms. However, when the sample was stratified as high or low customer concentration and different cost structures, JIT firms with low customer concentrations showed significantly higher ROA than non-JIT firms. Extending the study by Balakrishnan et al., Kinney and Wempe (2002) used a similar matched-pair research design to investigate the profitability of JIT and non-JIT firms. Inconsistent with the earlier study, their results indicate that the ROA of the JIT firms fell significantly less compared to the non-JIT firms when tested after three post-JIT adoption years.

A more recent study by Fullerton et al. (2003) provides empirical support for the relationship between the degree of JIT practices used and profitability. In this study, JIT implementation was measured using an 11 item instrument comprising three dimensions: JIT manufacturing, quality and unique JIT. In addition, three separate measures of profitability were used: return on sales (ROS), ROA and cash flow margin (CFL). They found positive significant relationships between JIT manufacturing practices and profitability supporting the premise that firms that implement higher degrees of JIT manufacturing practices should perform better than those who do not. However, contrary to expectation, the degree of JIT 
quality practices was inversely and significantly related to firm profitability. They argue that these results are "not conclusive since they imply either that the degree of implementation of JIT quality indicators reduces profitability, or firms with low profitability recognize their strategic disadvantage and increase their focus on quality improvement by implementing JIT quality processes". (Fullerton et al. 2003, p.400). On the other hand, the JIT unique measure shows no significant relationship with profitability. The earlier studies indicate inconsistent and inconclusive evidence of the nature of the relationship between JIT practices and profitability and this warrants further investigation.

\subsection{Research Hypotheses}

The aims of this research are to examine the level of JIT implementation among Malaysian manufacturing firms and to evaluate empirically the relationship between JIT implementation and performance. The research hypotheses are as follows:

$\mathrm{H}_{1}=$ There is a positive relationship between the level of JIT implementation and business performance.

$\mathrm{H}_{1 \mathrm{a}}=$ There is a positive relationship between the level of JIT implementation and financial business performance.

$\mathrm{H}_{1 \mathrm{~b}}=$ There is a positive relationship between the level of JIT implementation and nonfinancial business performance.

\section{Research Method}

\subsection{Survey and Sample Design}

The research was undertaken using a survey design, where primary data was obtained from companies operating in the Malaysian manufacturing sector. To test the research hypotheses, a survey questionnaire was designed to collect specific information about the manufacturing operations, JIT implementation, perceived firm performance and the characteristics of the respondents and the sample firms. The survey instrument was subjected to a limited pre-test to check for relevance, readability, completeness and clarity. The feedback was sought from several academicians and managers of five manufacturing firms who are familiar with JIT practices. Relevant and appropriate changes were made accordingly, taking into account the comments and suggestions from the respondents of the pre-test.

The sample comprised manufacturing companies listed in the 2005 Federation of Malaysian Manufacturers (FMM) Directory. Due to time and cost constraints ${ }^{1}$, a total of 150 manufacturing companies in the Klang Valley and Northern Region of Peninsular Malaysia were conveniently selected. Questionnaires were distributed through postal mail and email. A self-addressed envelope was enclosed with the questionnaire to enable the respondents to return the questionnaire. Follow-up telephone calls were made to ensure that the companies received the questionnaires.

\subsection{Measures of JIT Implementation and Performance}

The current study focuses on two major aspects of JIT: manufacturing and purchasing. In this study, JIT implementation focuses on JIT purchasing and manufacturing practices and it is measured as the extent to which selected JIT manufacturing and purchasing practices are used, similar to the approach used in prior research (e.g. Banker; Banker et al., 1993b; Flynn; Sakakibara and Schroeder, 1995), which measured JIT implementation levels based on a representative set of JIT manufacturing practices.

In this study, JIT is not measured as a formal programme because the study does not only focus on JIT adopters. The respondents were not specifically asked whether JIT is used

\footnotetext{
${ }^{1}$ This project was part of an MBA course requirement and was carried out over a period of three months.
} 
as a formal management as it was conjectured that many firms may not have JIT as a formal programme, but can have operations similar to JIT characteristics. In addition, this will allow a higher number of companies to participate in the survey as it was conjectured that only a small number of companies in Malaysia have implemented a formal JIT programme in their organisations.

Based on the literature, six measurable manufacturing practices that reflect JIT purchasing and manufacturing practices were selected to represent JIT implementation for the purpose of this study. JIT implementation is measured using a six item instrument to measure the extent of JIT practices adopted by the sample firms using a five point Likert scale ranging from 1 (least extent) to 5 (greatest extent). Although not all inclusive, these six practices are: sampling check, supplier access to production schedule, manufacture after receive order, use single cell production, quality checks on raw material, and deliver goods based on company's production schedule. These measures were selected because they represent the common JIT practices used in companies and thus could be considered as a surrogate measure for JIT implementation. Instead of asking the respondents to state whether they have a formal JIT programme, the respondents were asked to state the extent of JIT implementation based on those practices. This approach was considered to be more appropriate for data collection purposes as some companies may be using some elements of JIT even though they do not have a formal JIT programme.

Self-reported business performance as used by Mia and Clarke (1999) and Khandwalla $(1972,1977)$ is used to measure business performance. Mia and Clarke (1999) define business unit performance as "the extent to which the unit had been successful in achieving its planned target(s), such as achievement of planned productivity, costs, quality, delivery schedule, sales volume, market share, and level of profit" (p. 151). A five-point Likert scale, 1 representing 'poor performance' and 5 representing 'excellent performance', was used. Managers were asked to indicate their last three years' actual performance compared to the planned performance by considering only those performance targets that are relevant to their firms. Mia and Clarke (1999) argue that this broad approach of performance assessment has an advantage over the 'return on investment' (ROI) or input output ratio method of performance measure because it incorporates all aspects (qualitative and quantitative, financial and non-financial) of business performance. In contrast, the conventional performance evaluation methods such as ROI and input/output ratio consider only the quantitative aspects. Self-reported measure of performance is used in other studies such as Govindarajan (1988), Govindarajan and Fisher (1990), and Chenhall and LangfieldSmith (1998) in which respondents were asked to assess their business' performance relative to competitors over the last three years. In this study, respondents were asked to rate their firms' performance over the last three years using a five-point Likert scale, 1 representing 'poor performance' and 5 representing 'excellent performance'. An 8-items instrument comprising the following items was used: profit, cost savings, on-time delivery, improvement in manufacturing time, product quality, space saving, improvement in purchasing lead time and product innovation.

\section{Results and Discussion}

The findings will be presented in the following order: profile of the sample firms and the respondents, descriptive statistics of the main variables and, lastly, the statistical associations between JIT implementation and performance 
Table 1: Profile of Respondents

\begin{tabular}{llll}
\hline Backgrounds & Categories & Frequency & Percentage \\
\hline Age & 21 to 30 years old & 32 & 42 \\
& 31 to 40 years old & 34 & 44.7 \\
\multirow{3}{*}{ Gender } & 41 to 50 years old & 9 & 11.8 \\
& above 51 years old & 1 & 1.3 \\
Education Background & Male & 35 & 46.1 \\
& Female & 41 & 53.9 \\
& Diploma and Advance Diploma & 2 & 2.6 \\
& Degree & 61 & 80.3 \\
Length of service & Master & 9 & 11.8 \\
& Professional Course & 4 & 5.3 \\
& 0 to 2 years & 10 & 13.2 \\
Occupation Level & above 2 to 5 years & 26 & 34.2 \\
& above 5 to 10 years & 18 & 23.7 \\
& more than 10 years & 22 & 28.9 \\
& Director & 1 & 1.3 \\
& Engineer & 28 & 10.5 \\
& Manager & 29 & 38.2 \\
& Executive & 38 & 50.0 \\
\hline
\end{tabular}

\subsection{Profile of Respondents and Companies}

Table 2: Profile of Sample Firms

\begin{tabular}{llll}
\hline Background & Categories & Frequency & Percentage \\
\hline Types of Industry & Foods \& Beverages & 9 & 11.8 \\
& Textiles \& Clothing & 9 & 11.8 \\
& Wood products & 4 & 5.3 \\
& Chemical & 8 & 10.5 \\
& Metal products & 6 & 7.9 \\
& Rubber products & 2 & 2.6 \\
& Electrical \& electronics & 10 & 13.2 \\
& Plastic products & 3 & 3.9 \\
& Others & 25 & 32.9 \\
Annual Sales & Under RM 5 million & 4 & 5.3 \\
& RM 5 to under RM 20 million & 27 & 35.5 \\
& RM 20 to under RM 30 million & 17 & 22.4 \\
& RM 30 to under RM 50 million & 7 & 9.2 \\
Ownership & above RM 50 million & 21 & 27.6 \\
& Local & 29 & 38.5 \\
Total Shareholders Funds & Foreign & 32 & 42.1 \\
& Joint Venture & 15 & 19.7 \\
& Less than RM 2.5 million & 8 & 10.5 \\
& Between RM 2.5 - RM 25 million & 36 & 47.4 \\
Full Time Employees & Between RM 26 - RM 50 million & 22 & 28.9 \\
& Above RM 50 million & 10 & 13.2 \\
& Below 500 & 39 & 51.3 \\
& 501 - 1000 & 25 & 32.9 \\
& 1001 - 1500 & 5 & 6.6 \\
& Above 2500 & 7 & 9.2 \\
\hline
\end{tabular}

A total of 87 questionnaires were received but 11 were not valid or were incomplete and as such were rejected. Finally, 76 questionnaires were selected for final analysis giving a response rate 50.6 percent. Table 1 shows the profile of the respondents. In terms of age, the 
largest group of respondents was 31 to 40 years old (44.7\%), followed by the 21 to 30 age group (42\%), and 11.8 percent of the respondents were 41 to 50 years old. There were 35 $(46.1 \%)$ male respondents and $41(53.9 \%)$ female respondents.

With regards to educational background, the majority of the respondents $(80.3 \%)$ had a degree as shown in Table 1. More than 50 percent of them have served their companies for more than five years. The majority of the respondents were in the middle management group as 88.2 percent of them were managers and executives.

Table 2 shows the sample firms were from various industries. In terms of annual sales, more than half of the firms had less than RM30 million of sales and foreign firms represented almost half (42\%) of the respondents. Most of the companies (51.3\%) have an average of less than 500 full time staff. Almost 60 percent of the sample firms were in the small and medium size category with shareholders' equity of less than RM25 million.

\subsection{Descriptive Analysis and Reliability}

Table 3 shows the descriptive statistics for the JIT implementation variable. The overall mean is 3.42 suggesting a moderate level of JIT implementation for the whole sample. The highest mean value (3.75) is shown for the item 'delivery of goods based company's production schedule' while the lowest (2.66) is for 'supplier access to production schedule', suggesting the most and the least common JIT practices among the sample firms.

\section{Table 3: Descriptive Statistics for JIT Implementation Variable}

\begin{tabular}{|c|c|c|c|c|}
\hline \multirow[t]{2}{*}{ Item } & \multirow[t]{2}{*}{ Mean } & \multirow{2}{*}{$\begin{array}{l}\text { Standard } \\
\text { Deviation }\end{array}$} & \multicolumn{2}{|c|}{ Actual Range } \\
\hline & & & Min & Max \\
\hline Overall & 3.42 & 0.65 & 1.43 & 5 \\
\hline Sampling check & 3.63 & 0.85 & 2 & 5 \\
\hline Supplier access to production schedule & 2.66 & 1.14 & 1 & 5 \\
\hline Use single cell production & 3.36 & 1.26 & 1 & 5 \\
\hline $\begin{array}{l}\text { Quality checks on raw material by } \\
\text { suppliers }\end{array}$ & 3.61 & 1.06 & 1 & 5 \\
\hline $\begin{array}{l}\text { Deliver goods based on company's } \\
\text { production schedule }\end{array}$ & 3.75 & 1.01 & 1 & 5 \\
\hline Manufacture after receive order & 3.63 & 1.02 & 1 & 5 \\
\hline Cronbach's alpha: 0.612 & & & & \\
\hline
\end{tabular}

Table 4 displays the descriptive statistics for self-reported or perceived business performance. Table 4 indicates that the majority of the variables' mean values are higher than 3.0 except for innovation introduced scored 2.79, suggesting that on average, most of the respondents felt that their firms were performing at above average compared to their competitors, especially with respect to factory or space saving (mean=3.42) and cost savings $($ mean=3.33). The firms also perceived that they were performing above average in terms of on-time delivery $($ mean $=3.28)$ and product quality (mean=3.28).

Reliability of the measures was checked using Cronbach's alpha reliability of coefficient based on Nunnally's (1978). The independent variable (JIT implementation) was measured by six items. The value of Cronbach's alpha is 0.612 . The dependent variable (performance) was measured by eight items and the Cronbach alpha is 0.628 . As the alpha value was above the average value of 0.600 , the internal consistency of the reliability of these measures is reasonably good. 
Table 4: Descriptive Statistics for Business Performance

\begin{tabular}{|c|c|c|c|c|}
\hline \multirow[t]{2}{*}{ Criteria } & \multirow[t]{2}{*}{ Mean } & \multirow{2}{*}{$\begin{array}{l}\text { Standard } \\
\text { Deviation }\end{array}$} & \multicolumn{2}{|c|}{ Actual Range } \\
\hline & & & Mini & Max \\
\hline Overall Performance & 3.20 & 0.43 & 1.63 & 4.13 \\
\hline \multicolumn{5}{|l|}{ Financial: } \\
\hline Profit before Tax & 3.14 & 0.88 & 1 & 5 \\
\hline Cost Savings & 3.33 & 0.76 & 1 & 4 \\
\hline \multicolumn{5}{|l|}{ Non Financial: } \\
\hline On-time delivery & 3.28 & 0.87 & 1 & 5 \\
\hline Manufacturing time & 3.18 & 0.62 & 2 & 4 \\
\hline Product quality & 3.28 & 0.76 & 2 & 4 \\
\hline Space saving & 3.42 & 0.90 & 1 & 5 \\
\hline Reduce purchasing time & 3.14 & 0.91 & 1 & 5 \\
\hline Innovation & 2.79 & 0.85 & 1 & 4 \\
\hline Cronbach's alpha: 0.628 & & & & \\
\hline
\end{tabular}

\subsection{Hypotheses Testing}

Before running the regression analysis, correlation analysis was carried out to obtain some indications whether JIT and performance are correlated. The results of the analysis are shown in Table 5.

Table 5: Correlation between JIT Implementation and Performance

\begin{tabular}{|c|c|c|c|c|}
\hline & $\begin{array}{l}\text { JIT } \\
\text { implementation }\end{array}$ & $\begin{array}{l}\text { Overall } \\
\text { Performance }\end{array}$ & $\begin{array}{l}\text { Financial } \\
\text { performance }\end{array}$ & $\begin{array}{l}\text { Non-financial } \\
\text { performance }\end{array}$ \\
\hline \multicolumn{5}{|l|}{ JIT } \\
\hline implementation & 1 & & & \\
\hline $\begin{array}{l}\text { Overall } \\
\text { Performance }\end{array}$ & $\begin{array}{l}0.482 \\
(p=0.000)\end{array}$ & 1 & & \\
\hline $\begin{array}{l}\text { Financial } \\
\text { performance }\end{array}$ & $\begin{array}{l}0.447 \\
(p=0.000)\end{array}$ & $\begin{array}{l}0.973 \\
(p=0.000)\end{array}$ & 1 & \\
\hline $\begin{array}{l}\text { Non-financial } \\
\text { performance }\end{array}$ & $\begin{array}{l}0.312 \\
(p=0.006)\end{array}$ & $\begin{array}{l}0.482 \\
(\mathrm{p}=0.000)\end{array}$ & $\begin{array}{l}0.266 \\
(\mathrm{p}=0.020)\end{array}$ & 1 \\
\hline
\end{tabular}

The results indicate the presence of significant correlations between JIT implementation and overall performance $(\mathrm{r}=0.482)$ at significance level 0.01 . The correlation between financial performance (profit and cost saving) and JIT implementation is also significant $(\mathrm{r}=0.447)$ at significance level 0.01. Similarly, JIT implementation is significantly correlated with non-financial performance $(\mathrm{r}=0.312)$ at significance level 0.01 . These results suggest the two variables are significantly correlated, thus, initial support for further analysis to test the hypotheses.

To test the research hypotheses, regression analyses were carried out to examine the relationship between JIT implementation and performance. Table 6 displays the results of the regression analysis. The regression results indicate that a significant and positive relationship exists between JIT implementation and overall performance, thus, lending support to Hypothesis $1\left(\mathrm{H}_{1}\right)$. Similarly, JIT implementation is positively and significantly related with financial as well as non-financial performance. Hence, sub-hypotheses $\mathrm{H}_{1 \mathrm{a}}$ and $\mathrm{H}_{1 \mathrm{~b}}$ are also supported. The results also indicate JIT implementation explains almost 24\%, $11 \%$ and 18\%, respectively, of the changes in overall, financial and non-financial performance. 
Table 6: Summary of Results of Regression Analyses

\begin{tabular}{llll}
\hline Independent Variable & \multicolumn{2}{l}{ Dependent Variable: Performance } \\
\cline { 2 - 4 } & $\begin{array}{l}\text { Overall } \\
\text { performance }\end{array}$ & $\begin{array}{l}\text { Financial } \\
\text { performance }\end{array}$ & $\begin{array}{l}\text { Non-financial } \\
\text { performance }\end{array}$ \\
\hline JIT implementation & $0.488^{* * *}$ & $0.332^{* * *}$ & $0.438^{* * *}$ \\
$\mathrm{R}^{2}$ & 0.238 & 0.110 & 0.192 \\
Adj. $\mathrm{R}^{2}$ & 0.227 & 0.098 & 0.181 \\
$\mathrm{~F}$ & $23.079^{* * *}$ & $9.159^{* * *}$ & 17.585 \\
\hline
\end{tabular}

$* * * \mathrm{p} \leq 0.01, * * \mathrm{p} \leq 0.05, * \mathrm{p} \leq 0.10$

Table 7: Results of Multiple Regression Analyses

\begin{tabular}{|c|c|c|c|}
\hline \multirow[b]{2}{*}{$\begin{array}{l}\text { Independent Variable: JIT } \\
\text { Implementation }\end{array}$} & \multicolumn{3}{|c|}{ Dependent Variable: Performance } \\
\hline & $\begin{array}{l}\text { Overall } \\
\text { Performance }\end{array}$ & $\begin{array}{l}\text { Financial } \\
\text { performance }\end{array}$ & $\begin{array}{l}\text { Non-financial } \\
\text { performance }\end{array}$ \\
\hline Sampling check & $0.311 * *$ & 0.196 & $0.287 * *$ \\
\hline $\begin{array}{l}\text { Supplier access to production } \\
\text { schedule }\end{array}$ & $0.250 * *$ & $0.486 * * *$ & 0.100 \\
\hline Manufacture after receive order & 0.000 & 0.042 & -0.020 \\
\hline Use single cell production & -0.128 & -0.148 & -0.86 \\
\hline $\begin{array}{l}\text { Quality checks on raw material by } \\
\text { suppliers }\end{array}$ & $0.203 *$ & -0.048 & $0.270 * *$ \\
\hline $\begin{array}{l}\text { Deliver goods based on } \\
\text { company's production schedule }\end{array}$ & $0.297 * *$ & 0.187 & $0.274 * *$ \\
\hline $\mathrm{R}^{2}$ & 0.343 & 0.207 & 0.333 \\
\hline Adj. $R^{2}$ & 0.286 & 0.138 & 0.275 \\
\hline $\mathrm{F}$ & $6.004 * * *$ & $3.008 * *$ & $5.734 * * *$ \\
\hline
\end{tabular}

To further explore the roles of each JIT implementation variable in predicting the performance, multiple regression analyses were carried out. The regression results shown in Table 7 show overall performance is significantly related with three variables (sampling check, supplier access to production schedule and supplier delivers goods based on company's production schedule) at a significance level of 0.05 . With regards to financial performance, only one factor 'supplier access to production schedule' is significantly related at a significance level of 0.001 . On the other hand, non-financial performance is related to three factors at a significance level of 0.05: sampling check, quality checks on raw material by suppliers, and supplier delivers goods based on company's production schedule.

\section{Conclusion}

The main purpose of this study is to examine whether JIT implementation is related to business performance. It is hypothesized that JIT implementation is positively related to overall, financial and non-financial performance. The survey results reveal a moderate level of JIT implementation among the sample firms. In terms of level of performance, generally, the sample firms reported above average performance in all performance indicators, except innovation.

Overall, the results of correlation and regression analyses provide support to the hypotheses, suggesting JIT implementation is one of the predictors of performance in manufacturing firms in Malaysia. The results are consistent with the findings of other empirical studies such as Inman and Mehra (1993) who reported a significant correlation between self-reported improvement in performance and the adoption of JIT practices. 
However, the results of studies that define financial performance as reported profitability or ROA show mixed results (Balakrishnan et al., 1996; Fullerton et al., 2003; Huson and Nanda, 1995; Inman and Mehra, 1993; Kinney and Wempel; 2002). The inconsistent findings on the nature of the relationship between JIT practices and profitability suggest that further investigation in this area of research is much warranted.

The results of the study, however, are subject to several limitations. First, the study is associated with the usual limitations of cross-sectional survey research, namely data collected at a single point of time. Second, this study covers only manufacturing firms and uses a nonrandom sample. It is possible the effects of JIT implementation on performance may be different for other sectors, such as the services sector. Third, the majority of the respondents in the survey were middle-level managers and were not the senior or top-level managers as initially planned. Thus it may be possible that the respondents might have been unfamiliar with the questionnaire terms used to describe JIT implementation and performance and also there may be differences in perceptions between the two groups of managers. In addition, the sample size in this study is relatively small, which limits the use of more powerful statistical tests as well as generalisability of the research results. Fourth, the survey instruments used to measure JIT implementation and performance were developed based on the relevant literature, they might not have been completely indicative of actual company practices. Lastly, as indicated by the $\mathrm{R}^{2}$ and adjusted $\mathrm{R}^{2}$ in the regression models, there may be other important predicting variables that could be added to the model to improve its explanatory power.

In view of the limitations above, future research could further investigate the nature and degree of JIT implementation through the use of a larger sample and to include other sectors such as the service industry. The instruments for the JIT implementation and performance could be further improved.

\section{References}

Ansari, A. and Modarress, B. (1990), Just-In-Time Purchasing, The Free Press, NY.

Balakrishnan, R.Linsmeier, T.J., Venkatachalam, M. (1996), "Financial benefits from JIT adoption: effects of customer concentration and cost structure", The Accounting Review, Vol. 7, No. 2, 183-205.

Banker, R., Potter, G. and Schroeder, R., (1993). "Reporting manufacturing performance measures to workers: an empirical study". Journal of Management Accounting Research, Vol. 5, pp. 33-53.

Banker, R., Potter, G., Schroeder, R., (1993b). "Manufacturing performance reporting for continuous quality improvement”, Management International Review, Vol. 33 (Special Issue), 69-85.

Browne, J.(1995), "Forecasting demand for services", Industrial Engineering, February, 1617.

Carr, C.H. and Truesdale, T.A. (1992), "Lessons from Nissan's British Suppliers", International Journal of Operations \& Production Management, Vol. 12, No.2, 4957.

Cobb, I. (1993), JIT and the Management Accountant: A Study of Current UK Practice, CIMA, London.

Das.C and Goyal, S.K. (1989), "A vendors view of the JIT Manufacturing Systems", International Journal of Operations \& Production Management, Vol. 9 No.8, 106111.

Fieten, R. (1989), "Integrating key suppliers essential part of a JIT concept", Engineering Costs and Production Economics, Vol.15, 185-189. 
Flynn, B.B., Sakakibara, S. and Schroeder, R.G., (1995). "Relationship between JIT and TQM: practices and performance". Academy of Management Journal Vol. 38, pp. $1325-1353$

Fullerton, R.R., McWatters, C.S. and Fawson, C. (2003), "An examination of the relationships between JIT and financial performance", Journal of Operations Management, Vol. 21, 383-404.

Galhenage, G. et al. (1997), "Just-in-time manufacturing", http://rolf.ece.curtin.edu.au/ $\sim$ clive/jit/jit.htm

Giunipero, L.C. (1990), "Motivating and monitoring supplier performance", Purchasing and Materials Management, Vol. 126. No.3, 19-24.

Hay, E.J. (1990), "Implementing JIT purchasing and inventory", Management Review, Vol. 10, No. 4, 38-40.

Huson, M. and Nanda, D. (1995), "The impact of just-in-time manufacturing on firm performance in the US", Journal of Operations Management, Vol. 12, 297-310.

Inman, R.A., and Mehra, S. (1993), "Financial justifications of JIT implementation", International Journal of Operations and Production Management, Vol. 14, No. 4, 3239.

Johnson, H.T. and Kaplan, R.S. (1989), Management by accounting is not management accounting", The Accounting Systems Journal, Fall, 14-17.

Kant, R and Grenoble, W.L. (1991), "modelling the effects of traffic congestion on JIT", International Journal of Physical Distribution \& Logistics Management, Vol.21, No. 2, 3-9.

Kinney, M.R. and Wempe, W.F. (2002), "Further evidence on the extent and origin of JIT's proftability effects", The Accounting Review, Vol. 77, No. 1, 203-225.

Leavy, B. (1994), "Two strategic perspective on the buyer-supplier relationship", Production and Inventory Management Journal, Vol. 35, No.2, 47-51.

Lothian, N. (1999), "Measuring Corporate Performance", The Chartered Institute of Management Accountants.

Manoochehri, G.H. (1984), "Suppliers and just-in-time concept", Journal of Purchasing and Materials Management, Vol. 20, No.4, 16-21.

O' Neal, C. R(1987), "The buyer-seller linkage in a JIT environment “, Journal of Publishing and Materials Management, Vol. 23. No.1, 7-13.

Ptak, C. (1987), MRP and Beyond: A toolbox for Integrating People and Systems, Irwin, Chicago, IL.

Ramsay, J and William, T. (1990), "Sourcing/contracting strategy selection", International Journal of Operations \& Production Management, Vol. 10, No.8, 19-28.

Schonberger, R and Ansari, A. (1994), "Just-in-time Purchasing can improve quality", Journal of Purchasing and Materials Management, Vol 20. No.1, 2-7.

Shannon, P. (1993), "Push/pull manufacturing simulation: a hands-on training experience". Production and Inventory Management Journal, 1st Quarter, 13-17.

Shingo, S. (1981), Study of Toyota Production System: From Industrial Engineering Viewpoint. Japan Management Association, Tokyo.

Sinnamon, G. (1993), "Just-in-time Schedules for the Small Make to Order Shop", Canadian Journal of Administrative Sciences, December, 340-351.

Stevenson, W.J. (1996), Production/Operations Management, Irwin, Chicago, IL.

White, R.E. and Ruch, W.A. (1990), "The composition and scope of JIT", Operations Management Review, Vol. 7, No. 3/4, 9-18.

Willis, H.T. (1992), "Supplier certification: concepts and techniques", Logistics Information Management, Vol.5 No.1, 32-38. 
Yasin, M.M., Small, M. and Wafa, M. (1997), "An empirical investigation of JIT effectiveness: an organizational perspective", Omega, Vol. 25, No. 4, 461-471. 